\title{
Relacje dorosłych niepełnosprawnych intelektualnie ze znaczącym Innym - perspektywa biograficzna
}

Relacje interpersonalne ze znaczącymi Innymi są niezwykle ważne dla osób z niepełnosprawnością intelektualna. Relacje te budują ich dorosłe życie, ponieważ określają sposób doświadczania i interpretowania trudów dnia codziennego. Celem artykułu jest przedstawienie wyników badań dotyczących osób z umiarkowaną niepełnosprawnością intelektualną, doświadczających i interpretujących własne relacje ze znaczącymi Innymi. Prezentowane badania przeprowadzono w orientacji jakościowej, co pozwala na zastosowanie metody biograficznej i wywiadu narracyjnego. Analiza materiału empirycznego ukazuje biografie ludzi, z perspektywy wydarzeń i sytuacji budujących ich życie.

Słowa kluczowe: znaczący Inni, relacje, dorosłość, niepełnosprawność intelektualna

\section{Relations between adults with intellectual disabilities and significant Other - biographical perspective}

Interpersonal relations with significant Other are extremely important for people with intellectual disabilities. That relations construct their adult life because they determine the way of experiencing and interpreting everyday's difficulties. The aim of the article is to present the result of studies related to people's with moderate intellectual disabilities experiencing and interpreting their relations with significant people. Presented researches were conducted in a qualitative orientation which allows using biographical method and narrative interview. The analysis of the empirical material shows biographies of people that shows events and situations constructing their lives.

Keywords: significant Others, relations, adulthood, intellectual disability

\section{Wprowadzenie}

Człowiek - jako istota społeczna - zaspokaja swoje ważne życiowo potrzeby w interakcjach z innymi ludźmi. Umiejętność nawiązywania relacji i ich podtrzymywania pozwala wpływać każdej osobie na swoje życie i otoczenie. Naturalnym produktem relacji jest wsparcie społeczne, będące jednym z czynników odgry- 
wających ważną rolę w utrzymaniu dobrego samopoczucia w ciągu życia (ZhenQiang i in. 2010: 108-112). Wsparcie to definiuje się m.in. jako przynależność społeczną, stopień zobowiązania i bliskości lub jako dostępność relacji (Knoll, Schwarzer 2005: 29). Barierą w zaspokajaniu interpersonalnych potrzeb człowieka jest osamotnienie. Osoba doświadczająca samotności izoluje się, co w konsekwencji prowadzi do zaburzonych kontaktów z innymi, poczucia odrzucenia i nieprzydatności, braku inicjatywy oraz wrogości.

Relacje człowieka z innymi ludźmi są więc istotnym elementem życia - pisze Błeszyńska - i zależne są od wielu czynników. Jednym z ważniejszych jest kategoryzowanie świata społecznego na "tacy jak ja - inni, my - oni, swoi - obcy” (2001: 85). Kategorie te powstają w wyniku postrzegania ludzi, które „polega na przypisywaniu przez podmiot innym właściwości, oczekiwań oraz na powstawaniu związanych z nim emocji podmiotu" (Krawiecka 2014: 28). Biorąc pod uwagę kryteria przynależności grupowej, osoby z niepełnosprawnością są szczególną grupą. Są „swoi”, bo współtworzą z pełnosprawnymi niemal wszystkie struktury społeczne, zarówno małe grupy (rodzina, grupa sąsiedzka, rówieśnicza, szkolna czy pracownicza), jak i wielkie grupy (naród, państwo, grupy płci czy wieku), ale są równocześnie "obcy”, ponieważ różnią się pod wieloma względami, w tym również pod względem możliwości społecznego funkcjonowania (Chodkowska, Szabała 2012: 70).

Dysonans w zakresie postrzegania „innych”, , obcych” oraz relacji z nimi sprawia, że problematyka kontaktów społecznych osób sprawnych z niepełnosprawnymi jest wciąż aktualna - podkreśla Chrzanowska - i znajduje się w centrum zainteresowań przede wszystkim pedagogów, pedagogów specjalnych, oraz psychologów, socjologów i pedagogów społecznych (2015: 112). Hebl i Kleck prezentują liczne badania ukazujące osoby niepełnosprawne i trudności, których oni doświadczają w polu relacji społecznych (2008: 385). Przykładem może być kontakt z osobą niepełnosprawną w wyniku którego uznamy wartość tej osoby, a w konsekwencji dojdzie do zmniejszenia obciążenia emocjonalnego podczas tego kontaktu i zmiany postawy na pozytywną. Zmiana taka może być też ukierunkowana w drugą stronę, gdzie zwiększenie obciążenia psychicznego spowoduje zmianę postawy podczas kontaktu na negatywną (Kirenko 2008: 33-34).

Negatywne nastawienie widoczne jest szczególnie wobec osób z niepełnosprawnością intelektualną, co potwierdzają m.in. badania przywołane przez Dycht. Wskazują one, że większość badanych nie widzi przeszkód w nawiązaniu relacji z osobami niepełnosprawnymi, a więc osoby te mogłyby być przełożonym, współpracownikiem, sąsiadem, znajomym czy przyjacielem lub krewnym osób z niepełnosprawnością intelektualną, jednak ci sami respondenci wskazali, iż nie chcieliby kontaktu z osobami niepełnosprawnymi intelektualnie i chorymi psychicznie (2014: 59,71). Badania te ukazują więc dużą dozę tolerancji dla osób z nie- 
pełnosprawnością fizyczną, natomiast niepełnosprawność intelektualna wciąż jest tą, która budzi strach, lęk i niepokój. Ponadto wskazuje się, że u osób z niepełnosprawnością intelektualną występują ograniczenia w zakresie umiejętności społecznych odnoszonych do relacji interpersonalnych (Ćwirynkało 2009: 1667). Ograniczenia te oraz ujawniony w badaniach brak chęci do nawiązywania i utrzymywania relacji ze strony pełnosprawnych, powodować może izolację społeczną, odrzucenie i osamotnienie osób z niepełnosprawnością intelektualną, prowadzić może do całkowitego wycofania się z kontaktów społecznych (Papoutsaki i in. 2013: 51-56). Cała sytuacja wydawać by się mogła niepokojącą, ale Chrzanowska wskazuje, że wyniki współczesnych badań ujawniają poprawę sytuacji w zakresie postaw społecznych wobec osób z niepełnosprawnością (2015: 112), co może oznaczać także poprawę $\mathrm{w}$ zakresie relacji interpersonalnych.

Nie ulega wątpliwości, iż jakość dorosłego życia osób z niesprawnością intelektualną zależy w dużym stopniu od relacji z osobami znaczącymi, do których zalicza się przede wszystkim rodziców i osoby z najbliższego otoczenia, ale także wychowawców, przyjaciół, przełożonych. Oczywistym jest, że człowiek dla pełni swojego rozwoju potrzebuje takich osób, które stymulują go pozytywnie, inicjują rozwijanie umiejętności pozwalających sprostać wymaganiom społecznym, tak aby mógł aktywnie uczestniczyć we wszystkich płaszczyznach życia społecznego. Tak więc relacje ze znaczącymi Innymi mogą wpływać pozytywnie na dorosłość osób niepełnosprawnych intelektualnie i przyczyniać się m.in. do ich niezależności, odpowiedzialności, decyzyjności, samoakceptacji oraz sprawstwa w różnych zakresach społecznego egzystowania. Doświadczenia w zakresie relacji ze znaczącymi Innymi mogą także negatywnie kształtować osobowość i tożsamość osób z niepełnosprawnością intelektualną.

\section{Perspektywa badawcza}

Celem artykułu jest zaprezentowanie wyników badań dotyczących doświadczania i interpretowania przez dorosłe osoby z umiarkowaną niepełnosprawnością intelektualną relacji z osobami znaczącymi. Wyniki te są częścią większego projektu badawczego. Prezentowane badania zostały ulokowane w interpretatywnej strategii badawczej, która dąży do zrozumienia subiektywnego doświadczenia ludzkiego zdobywanego w trakcie życia (Rubacha 2004), oraz umożliwia "zabranie głosu tym, którzy na co dzień żyją na marginesie życia społecznego" (Rzeźnicka-Krupa 2011: 74). Stosowanie badań interpretatywnych jest więc zasadne ze względu na człowieka obarczonego niepełnosprawnością, który tworzy szerokie pole poznawcze. Przyjmując perspektywę jakościową następuje poszerzenie tego pola o problemy badawcze, na które można znaleźć odpowiedź, 
wychodząc poza to, co mierzalne i obiektywne. Tak więc zastosowanie orientacji jakościowej, pogłębionej o „rozumiejący wgląd w człowieka pozwalają odzwierciedlać strategie egzystencjalne pozwalające na co dzień żyć z niepełnosprawnością" (Żuraw 1999: 104).

Podstawowymi kategoriami poznawczymi stały się rozumienie i interpretacja, które pozwalają badaczowi w toku poznania stosować "empatię, introspekcje, subiektywne podejście, stanie na równi z badanymi osobami, badanie «od wewnątrz»" (Palka 2006, s. 77). Badacz stara się „\$łluchać i rozumieć badane osoby, odkrywać ich przeżycia wewnętrzne, a także analizować rzeczywistość z pozycji badanych, (...)"(tamże). Zrozumieć badane zjawisko, to znaczy zobaczyć je z perspektywy osób doświadczających go i odtworzyć przypisane mu subiektywne struktury znaczeniowe (Łobocki 2006: 93). Realizując projekt badawczy dominowała u mnie chęć „(z)rozumienia” osób z umiarkowaną niepełnosprawnością intelektualną. Celem badań stała się chęć poznania i zrozumienia, jak ta grupa osób doświadcza relacji społecznych ze znaczącymi Innymi, jak je interpretuje i jakiego znaczenia nadaje im w kontekście realizowanej dorosłości. Problem badawczy przyjął formę następującego pytania: Jak dorosłe osoby z umiarkowaną niepełnosprawnością intelektualną konstruują relacje z osobami znaczącymi i jak interpretują ich wpływ na swoje życie?

Zastosowanie jakościowej strategii badawczej pozwoliło wykorzystać metodę biograficzną oraz wywiad narracyjny. Biograficzne badania narracyjne dają możliwość wglądu w indywidualne doświadczenie jednostki, ale jednocześnie pozwalają dostrzec to, co społeczne, tj. kulturowy kontekst każdego doświadczenia. Dzięki tym badaniom możliwe staje się zrozumienie procesualnego charakteru naszego życia oraz „relacji między tym, co jednostkowe, a tym co intersubiektywne, społeczne, relacyjne" (Nowak-Dziemianowicz 2016: 84). Wywiad narracyjny pozwala pozyskać dane, które są nieosiągalne w inny sposób. Dane te są „żywsze, bo ludziom łatwiej opowiedzieć swoją historię (...) są pełniejsze i mniej ocenzurowane, (...)" (Konarzewski 2000: 122). Inspiracją do prowadzonych wywiadów nar- racyjnych z osobami z niepełnosprawnością intelektualną była dla mnie koncepcja Schützego (1997: 11), bowiem specyfika tego podejścia badawczego „umożliwia z jednej strony analizę struktur procesowych biografii (biograficzne plany działania, wzorce instytucjonalne przebiegu życia, trajektorie, przemiany biograficzne), a z drugiej pozwala na zrekonstruowanie procesu społecznego, w którym uwikłana jest jednostka" (Kędzierska 2012: 146).

Badane osoby mieszczą się w przedziale wiekowym pomiędzy 26. a 60. rokiem życia, mają zdiagnozowany umiarkowany stopień niepełnosprawności intelektualnej. Wśród nich jest 4 mężczyzn i 6 kobiet z różnych środowisk i o różnym statusie społecznym. Uczestnicy badania pochodzą z województwa warmińsko-mazurskiego. Wywiady przeprowadzono w okresie od lutego 2017 roku do lipca 
2018 r. Badania realizowane były głównie w miejscu zamieszkania rozmówców, ale także w warsztatach terapii zajęciowej, w których uczestniczą lub w miejscu ich pracy. Rozmówcy chętnie uczestniczyli w badaniu, które zostało poprzedzone wcześniejszymi spotkaniami, służącymi nawiązaniu takich relacji, które dałyby rozmówcom poczucie, że mogą swobodnie opowiadać o swoim życiu. Starałam się pozyskać zaufanie rozmówców, co w przypadku niektórych osób pochłaniało ogromną ilość czasu. Prowadzone wywiady trwały od 1,5 do 2,5 godzin i wymagały mojej ciągłej uwagi oraz bacznej obserwacji. Poniżej prezentuję krótką charakterystykę badanych, bowiem ich sytuacja rodzinna, zawodowa czy społeczna dostarcza danych kontekstowych do interpretacji uzyskanych wyników:

Mężczyzna nr 1 - lat 43, mieszka sam, kawaler, pracuje w zakładzie aktywności zawodowej w miejscu swojego zamieszkania jako stolarz;

Mężczyzna nr 2-lat 38, mieszka z rodzicami, kawaler, pracuje w zakładzie aktywności zawodowej w miejscu swojego zamieszkania jako stolarz;

Mężczyzna nr 3-lat 60, mieszka sam, kawaler, uczestnik warsztatów terapii zajęciowej;

Mężczyzna nr 4 - lat 34, mieszka z matką i siostrą, kawaler, pracuje jako stolarz na otwartym rynku pracy;

Kobieta nr 1-lat 44, mieszka z matką na wsi, panna, prowadzi gospodarstwo domowe;

Kobieta nr 2-lat 26, mieszka z rodzicami, panna, uczestniczka warsztatów terapii zajęciowej;

Kobieta nr 3 - lat 34, matka dwojga dzieci z niepełnosprawnością intelektualną, rozwódka, mieszka z matką ",chorą psychicznie”, pracuje w warsztatach terapii zajęciowej jako pomoc kucharza;

Kobieta nr 4-lat 32, mężatka, mąż odbywa karę pozbawienia wolności, wychowuje samotnie dziecko, pracuje jako sprzątaczka;

Kobieta nr 5 - lat 30, mieszka z rodzicami, panna, uczestniczka warsztatów terapii zajęciowej;

Kobieta nr 6 - lat 45, mężatka, mieszka z mężem, pracuje.

Ze względu na ochronę danych osobowych przyjęłam następujące kody: mężczyzna nr 1, mężczyzna nr 2 itd., oraz kobieta nr 1, kobieta nr 2 itd.

\section{Analiza materiału empirycznego}

W narracjach dorosłych osób z niepełnosprawnością intelektualną bardzo mocno wybrzmiewają doświadczenia wynikające z relacji z najbliższymi, ale także z innymi osobami z otoczenia lokalnego. Do znaczących Innych badani zaliczyli przede wszystkim rodziców, siostrę, męża, ale także przyjaciół oraz znajomych. 
Tak więc analizując biografie badanych można wyłonić następujące typy relacji: relacje rodzic-dorosłe dziecko, relacje między rodzeństwem, relacje uczuciowe, relacje przyjacielskie, koleżeńskie. Wymienione relacje są rzeczywiste, bezpośrednie. Opowiedziane historie wskazują na temporalny charakter tych relacji, a narratorzy nadają im subiektywne sensy i znaczenia, będące wynikiem ich doświadczenia i interpretacji. Z analizy narracji wynika, że najważniejsze relacje zostały ulokowane $\mathrm{w}$ trzech grupach: relacje rodzinne (rodzice, rodzeństwo), relacje uczuciowe (małżeństwo, związek, seksualność) oraz relacja partnerska (partner, kolega, przyjaciel, pracownik instytucji).

W ramach relacji rodzinnych badani dużo miejsca poświęcili relacjom z rodzicami. Z opowiedzianych historii wynika, że rozmówcy nie mówili tylko o czasie teraźniejszym, ale nawiązali także do przeszłości. Perspektywa czasowa pozwoliła uchwycić także zmienność w interpretacji tych relacji. Przykładem może być wypowiedź mężczyzny, który w przeszłości relację z rodzicami interpretował jako złą. Jego zdaniem więź ta była bardzo napięta, ponieważ dominowały w niej wyłącznie oczekiwania rodziców. Badany wówczas nie rozumiał z czego wynikają ich roszczenia i stawiał im opór. Dopiero z perspektywy czasu docenia starania rodziców i rozumie, że ich zachowanie było efektem troski o niego:

Mężczyzna nr 2: „W domu z rodzicami trochę się kłóciłem, tam..., jak na początku, jak kazali mi do pracy..., (...) bo mi dobrze było i ja nie chciałem tam..., (..) rozrywkowy byłem, (...), bawić się chciałem. (...) teraz to wiem, (...) że tam rodzice chcieli no dobrze, tak mnie wychować, ale ja bawić się chciałem. Teraz już się nie kłócę (śmiech)".

Rodzice są autorytetem dla badanego. Dorosły mężczyzna liczy się ze zdaniem rodziców np. w kwestii zawarcia małżeństwa. Ich decyzja wywiera ogromny wpływ na działanie rozmówcy, który rezygnuje z założenia rodziny, mimo, iż bardzo tego pragnie. Badany chciałby żyć ,jak wszyscy”, ale poddaje się woli rodziców:

Mężczyzna nr 2: „A nie wiem czy rodzice chcieliby, żebym się ożeniła, bo jeszcze o tym nie rozmawiałam, ale nie koniecznie, bo w tej chwili ważne jest żeby dawać pieniążki, żeby mieć pracę dobrą, żeby odkładać, odkładać i dopiero.... (...) ale mi się podoba taka jedna dziewczyna, ale rodzicom by się nie podobała, ale mi się podoba i ja bym chciał się ożenić i mieć dzieci, no tak jak wszyscy".

Mężczyzna nr 2: „Może kiedyś się ożenię... wiadomo, nie wiem, czy rodzicom będzie się to podobać?"

Istotna relacja $\mathrm{z}$ rodzicem wybrzmiewa w innej narracji. Kobieta postrzega łączącą ją więź z matką jako bardzo ważną, gdyż mówi, że tylko matka jest jej przyjaciółką:

Kobieta nr 3: „(...) przyjaciółka to jest moja mama..., tylko”. 
Kobieta nr 3: „(...) na razie mieszkam z mamą, na razie ona potrzebuje mojej pomocy, moja mama też jest chora..., ona nie da rady sobie, ona by zginęła jakbym ja odeszła..., strasznie by było...".

Badana opiekuje się chorą matką, chociaż sama potrzebuje wsparcia. Z narracji wynika, że w przeszłości relacje między kobietami nie były najlepsze. „Choroba psychiczna" matki spowodowała, że narratorka wspomina miniony czas jako okres samotności. Stara się bardzo, aby matka nie czuła się tak samotna, jak ona w dzieciństwie:

Kobieta nr 3: „No kiedyś to ona nie interesowała się mną..., nie? Nie była dobrą matką, bo ona chora jest, to wiadomo, nie? (...) ale ja bardziej sama byłam, no wiadomo".

Kobieta nr 3: „Tak szczerze to trochę mama mi pomagała (przy wychowaniu córki uzup. I.M.), ale też jest chora, trochę psychicznie, trochę ja więcej..., trochę ja więcej teraz jej pomagam... bo to matka, nie? Nie chcę żeby czuła się jak ja, nie? jak byłam samotna, wiadomo".

Podobnie jest w przypadku kolejnej narracji, gdzie matka była przyjaciółką dla badanej. Obecnie kobieta jest w związku małżeńskim i uważa, że teraz mąż przejął rolę jej przyjaciela:

Kobieta nr 6: „Mama byłą dla mnie, to tak można powiedzieć, że jak taka przyjaciółka, bo mogłyśmy porozmawiać no o wszystkim..., o tym jak się zakochałam też... (...), a teraz to Marek jest moim przyjacielem (...)"

Kobieta wspomina matkę jako autorytet. Mogła na nią liczyć w każdej sytuacji i można przypuszczać, że matka zyskała uznanie córki swoją mądrością życiową. Badana czuła się zawsze rozumiana i szanowana przez matkę:

Kobieta nr 6):„,Wcześniej jak miałam problem to do mamy szłam. Tak, do mamy, bo ona wszystko wiedziała. Mogłam ją zawsze zapytać, bo ona bardzo mądra była... To ja teraz już wiem jaką mam być żoną i jak ma się zachowywać kobieta dla męża (...) to była mądra kobieta, ona wiedziała wszystko, ale nie zadzierała nos wobec mnie, nie...".

$\mathrm{W}$ innej opowieści także została wskazana relacja z rodzicem jako bardzo znacząca. Ważną osobą w życiu badanej był ojciec, który swoją postawą sprawiał, że czuła się bezpieczna. Miała w nim ogromne wsparcie i zawsze mogła na niego liczyć, szczególnie kiedy doświadczała ośmieszenia i poniżana ze strony innych osób. Badana z rodzicami mieszkała na wsi, gdzie - jak wynika z narracji - nie zawsze była traktowana poważnie. Ojciec zawsze stawał w obronie badanej:

Kobieta nr 1: „(...) gorzej nam teraz jak Kazika (ojca - uzup. I. M.) nie ma, bo to nie tylko o to chodzi, że miał więcej siły, ale jak ktoś mi jakąś przykrość powiedział, to Kazik od razu szedł, opieprzył pani tak, że na pół wsi było słychać, i już nikt do mnie nie skakał. (...) tak było parę razy, ale potem to już ucichło i mam spokój". 
Podobnego znaczenia nabiera relacja z rodzicami dla kolejnej narratorki. Interpretuje ją ona jako troskę, opiekę, poczucie bezpieczeństwa. Kobieta obecnie samotnie wychowuje dziecko i czeka na powrót swojego męża. Z narracji wynika, że doświadczała przemocy ze strony męża, ale nie chciała dużo mówić na ten temat. Trudna sytuacja narratorki, znajduje duże zrozumienie i wsparcie ze strony rodziców, co ma ogromne znaczenie dla kobiety:

Kobieta nr 4: „Ja zawsze wiem, że oni..., że mama i tata troszczą się, no wiadomo jak o dziecko, i oni mi kiedyś powiedzieli..., tak dawno, jak mój mąż był niegrzeczny..., oni mi powiedzieli, że ja u nich zawsze będę bezpieczna, że... no wiadomo jak będę sama chciała".

Kobieta nr 4: „Ja wiem, że jak coś..., to ja tam u nich mam dom, (...) to już wiadomo, jakie to dla wszystkich ważne".

W niektórych fragmentach narracji bardzo mocno wybrzmiewa nadmierna kontrola rodziców, zarówno w odniesieniu do przeszłości jak i do czasu obecnego. Z narracji kobiety można wnioskować, iż rodzice nie uznali jej dorosłości, a w konsekwencji nie respektują potrzeb wynikających z jej wieku. Traktują ją jak dziecko i kontrolują każde jej działanie. Kobieta nie może samodzielne decydować i podejmować niezależnych decyzji w zakresie własnego, dorosłego życia:

Kobieta nr 2: „(...) no tak siedzieć cały czas w domu to źle, bo tak to tylko z mamusią do sklepu albo cioci idziemy, tak tak..., tatuś też krzyczy jak chcę wyjść gdzieś, (...)”.

Kobieta nr 2: „sama dojeżdżam na warsztaty, (...) my tu kawkę rano zawsze pijemy, pogadamy, pośmiejemy się. To jest życie, tak z ludźmi, razem (...) ale mamusia mnie odprowadza na przystanek..., (...) ubiera mnie w takie rzeczy brzydkie, albo jak czesze mnie to zawsze zakłada mi kokardę..., taką klamrę, (...) i śmieją się ze mnie na przystanku (...) a ja lubię chodzić w rozpuszczonych włosach, lubię je czesać, ale nie spinać".

Wśród relacji z bliskimi została wskazana więź z ojcem, w której badany stał się ofiarą przemocy psychicznej i fizycznej. Mężczyzna opowiada o bardzo zaburzonej relacji, która znacząco wpłynęła na jego dalszą biografię. Ojciec badanego nie zaakceptował niepełnosprawności syna i bardzo manifestował to swoim zachowaniem. Narrator czuł się bezsilny wobec zachowań ojca, które sprawiały mu przykrość. Miał świadomość, że jest niepełnosprawny i że nic tego stanu nie zmieni. Brak akceptacji ze strony ojca przyczyniał się do zaniżonego poczucia własnej wartości i do pogłębiania poczucia odrzucenia:

Mężczyzna nr 4: „Wtedy ja mało co rozumiałem, ale tak... później po osiągnięciu pełnoletności zacząłem bardziej pewne sprawy rozumieć. On po prostu chciał mieć zdrowego syna, a widzi pani jaki jestem, no nie tak to miało być".

Mężczyzna nr 4: „No nie powiem że było miło, bo on mi to pokazywał, że mnie nie cierpi, ale co ja mogłem zrobić? (...) czułem się jak wie pani, taki niepotrzebny, jak nikt ... (...). Kiedyś to mnie nawet dusić zaczął (...)". 
Brak więzi między ojcem i synem, a wręcz wrogość ojca do niepełnosprawnego syna, skutkuje obecnie tym, że dorosły już mężczyzna, chciałby być postrzegany inaczej niż jego ojciec:

Mężczyzna nr 4: „Chciałbym być inny, bo tak, w ogóle jaki ojciec taki synek...jak to się mówi..., ale ja nie jestem taki jak on. (...) zawsze o coś się czepiał, to źle, tamto też i tak cały czas, ale żeby powiedział coś miłego to nie, nie pamiętam powiem pani".

Mężczyzna nr 4: „(...) bo jakbym był taki jak on, to bym siedział i piwko, telewizor, wie pani jak to jest".

Mężczyzna nr 4: „(...) Myślałem wtedy, że nigdy nie będę taki jak on, że jak będę miał dzieciaka, to że będę go kochał, a nie tak wyzywał jak on mnie".

Przemocy w relacji z rodzicami doświadczył także inny mężczyzna. Była to przemoc finansowa. Otrzymywane wynagrodzenie badany przekazywał w całości rodzicom, gdyż taka była ich wola:

Mężczyzna nr 2: „Ja zarabiałem, ale pieniążki oddawałem rodzicom. No trzeba było pomóc... a jak pojechałem $\mathrm{z}$ chłopakami na mecz to nawet na piwo nie miałem (...), no nie podobało mi się to i kłóciłem się, bo wiadomo, każdy chce mieć pieniążki jakieś...".

Mężczyzna nr 2: „(...) nic nie miałem, zabierali mi wszystko, (...) no kupowali mi spodnie albo buty, albo słodycze, ale ja chciałem sam wydawać jak sam zarobiłem...(...) nie podobało mi się to".

Druga grupa relacji rodzinnych odnosi się do rodzeństwa osób z niepełnosprawnością intelektualną. Z opowiedzianych historii można wnioskować, iż do znaczących Innych badani zaliczają swoje rodzeństwo. W przypadku fragmentu narracji zamieszczonego poniżej, jest to relacją z siostrą, która swoją postawą zawsze stwarzała badanej poczucie bezpieczeństwa. Od dziecka opiekowała się nią i kierowała jej życiem:

Kobieta nr 1: „Ja pani wiem, że na Bożenie zawsze, że ona zawsze mi we wszystkim pomoże, od małego tak było. Ona się mną bardziej zajmowała niż Danka (matka - uzup. I.M)".

Siostra jest osobą, która w życiu narratorki odegrała rolę przewodnika, prowadząc ją krok po kroku ku dorosłości. W biografii bardzo dużo miejsca poświęcono tej relacji, co może oznaczać, że dla badanej jest ona wyjątkowo ważna:

Kobieta nr 1: „(...) wszędzie razem chodziłyśmy, ale potem jak ona szkołe skończyła to do miasta poszła i tam już została, (...) a jak przyjeżdżała z internatu, to mi przywoziła takie dobre czekoladki, bo wie pani u nas to nawet sklepu nie ma, albo jakąś bluzkę ładną, albo jakąś inną rzecz, tak tak, Bożena mi podpowiadała, jak mam się ubrać do kościoła, albo do miasta, ona bardzo ładnie się ubiera". 
Kobieta nr 1: „Nieraz jak na zabawę szłyśmy, to ona mnie malowała, czesała i mi mówiła, co mam robić, żeby chłopak mnie jakiś poderwał (śmiech), (...) no powiem pani, że gdyby nie Bożena, to ja bym nie miała tak się kogo poradzić..."

Kobieta nr 1: „Pani ja robię to, co Bożena powie, bo ona zawsze chce dla mnie dobrze, a poza nią to ja nie mam nikogo, no czasami jeszcze Edek też doradza, ale on to bardziej w gospodarce, bo facet, a Bożena tak we wszystkim, (...) a to mi co kupi do chałupy czy do ubrania, to jak ona kupi, to na pewno to jest modne, ja wiem".

Dla innej rozmówczyni więź z siostrą jest także bardzo istotna. W relacji tej badana otrzymuje dużo wsparcia w dorosłym życiu. Zawsze może liczyć na pomoc siostry, która docenia starania badanej i szanuje jej decyzje:

Kobieta nr 4: „Bo nie wolno się poddawać..., bo jak ktoś pomaga to jest lżej. (...) Siostra mnie docenia za to, że daję sobie ze wszystkim radę, że się staram i jest ze mnie zadowolona, szwagier jest..., no oczywiście teście dają mi tą satysfakcję..., są dumni i zadowoleni, że daję sobie z tym wszystkim radę, że jestem odpowiedzialna, że się staram... (...) ale siostra nigdy mi nie powiedziała, że coś robię źle albo coć..."

Kobieta nr 4: „Z siostrą..., do siostry dzwonię..., z siostrą zawsze mogę zawsze porozmawiać jak mam jakieś problemy. Z teściową sobie porozmawiam, czy ten...zawsze Cię ktoś tam wysłucha, czy coś tam doradzi..., tylko nie zawsze człowiek chce tam coś mówić..., ale najwięcej to z siostrą".

Kobieta nr 4: „Siostra dużo mi pomaga, jest moją oporą, bo zawsze mogę się wygadać”.

Kobieta $\mathrm{nr} 4$ : „(..) do siostry mogę zawsze zadzwonić, jak mam jakiś problem”.

W innej biografii mężczyzna także wspomina o relacji z siostrą, która rozumie jego potrzeby i jest mu bardzo bliska. Badany nie utrzymuje żadnych kontaktów z ojcem, który wyrzekł się go, natomiast więź z matką jest bardzo utrudniona przez jej chorobę. W tej sytuacji siostra jest jedyną bliską mu osobą:

Mężczyzna nr 4: „Tak pani powiem, że tylko siostra traktuje mnie jak dorosłego, to jest przykre, że nikt..., ale co zrobić. Dobrze, że chociaż ona, bo pani powiem, że ona zawsze mi pomoże, zawsze...".

Kolejna grupa relacji nawiązuje do związków uczuciowych. Z narracji wynika, że wyjątkową relacją była dla narratorki ta z przeszłości, w której doświadczyła uczucia miłości do mężczyzny. Spotkania, rozmowy, bliskość z ukochanym powodowały, że narratorka czuła się szczęśliwa:

Kobieta nr 1: „(...), jak ja go kochałam, tak lubiałam się do niego przytulać, bo ładnie pachniał. (...) pani on mówił mi, że jestem jego skarbusiem i mocno mnie przytulał. Ja chciałam mieć takiego męża, bo on mnie bardzo kochał i ja jego też (...)". 
Uczucie kobiety nie zyskało jednak aprobaty ojca:

Kobieta nr 1: „Ja już raz miałam chłopaka, ale wtedy Kazik (ojciec - uzup. I. M.) powiedział, że ma więcej do nas nie przychodzić. (...) On był z wioski tu obok, ale pani, on był taki ładny, jak ja go kochałam, tak lubiałam się do niego przytulać, bo ładnie pachniał. (...) i Kazik wtedy powiedział, że mam sobie znaleźć jakiegoś normalnego i go wtedy pogonił. Pani jak ja wtedy płakałam, jak tęskniłam za nim, uciekałam do niego, ale jak Kazik raz mi wpieprzył, to już wiedziałam, że żartów nie ma".

Powyższy fragment wskazuje, na ważność uczucia, które zostało przerwane decyzją ojca. Podczas opowiadania o byłym chłopaku, na twarzy badanej pojawiał się przejmujący smutek. Narratorka była z mężczyzną, który tak jak ona miał orzeczoną niepełnosprawność intelektualną. Ten związek dużo znaczył dla kobiety, która bardzo kochała swojego wybranka ze wzajemnością. Ojciec jednak nie zaakceptował niepełnosprawnego kandydata na zięcia, co doprowadziło do zerwania tej relacji. Obecny związek uczuciowy kobiety nie jest już tak ważny dla niej. Łącząca ją więź z mężczyzną nie została zbudowana na uczuciu miłości, ale raczej na obawie przed samotnością:

Kobieta nr 1: „Teraz pani jest inaczej, ja tak nie kocham Edka, ale samemu też jest źle (...). W sumie to nie wiem, czy Edek mnie kocha, ale chyba tak, bo by nie przychodził do mnie".

W innej biografii także została podkreślona waga relacji intymnej, uczuciowej i miłości, która tę więź buduje:

Kobieta nr 6: „(...) bo jakbym nie poszła do pracy, to bym Marka w pracy nie zapoznała. Było tak, że on tak przychodził po obiady i któregoś dnia przyszedł, poszedł tam na tą kuchnie, poprosił o mój numer telefonu, wleliśmy mu zupy i pojechał do domu. Ja się na drugi dzień po pracy z nim spotkałam. No i jak się spotkałam to już tu w Olszewce zostałam. No dał mi klucze do domu i tu już zostałam. A później mnie w Walentynki 14 lutego poprosił o zaręczyny tak, dał zaręczynowy pierścionek i później był w sierpniu 26 o 16:00 ślub. Akurat byliśmy dla siebie. Planowałam być żoną, przed Markiem byłam z chłopakiem, ale nam nie wyszło. Tak dwa miesiące. Tak się zastanawiałam czy dać Markowi mój numer telefonu czy nie dać, no i dałam, no i nie straciłam. (....) O założeniu rodziny pomyślałam jak z Markiem już byłam".

Kobieta nr 6: „Tulimy się do siebie, on tylko na mnie mówi: Kochanie, Słoneczko wszędzie i ja tak samo na niego. Inaczej na mnie nie powie, ja tak samo. Tak lubię, w sklepie tak tam. Pamiętam jak kiedyś w pracy powiedziałam: Mój kochany mąż, a koleżanka do mnie: Tylko kochany mąż, tylko kochany mąż, mów na niego, Marek, a nie kochany mąż. A Marek wszedł: Kochana żono! Takie przyzwyczajenie".

Relacja z mężczyzną to dla kobiety oznaka dorosłości. Kobieta wspomina bliską więź z matką, ale wówczas czuła się dzieckiem. Zamążpójście spowodo- 
wało, że poczuła się jak dorosła kobieta, która prowadzi samodzielne życie, a swoje problemy omawia z mężem:

Kobieta nr 6: „Dorosłą osobą, chyba jest łatwo, ale to nieraz tam, ale teraz jedność jest między nami to z mężem się rozmawia mimo wszystko. Jak nie byłam w związku to czułam się jak dziecko, a teraz jak jakiś problem mam to idę do Marka. Tak jak on ma jakiś problem to idzie do mnie. Tak się jedno od drugiego uczy. Wcześniej jak miałam problem to do mamy szłam (...) a teraz mam już męża".

Kobieta nr 6: „Jak ktoś ma męża albo żonę, to już nie chodzi do mamy rozmawiać o problemach tylko się rozmawia z tym mężem (...) bo to już nie jestem dzieckiem tylko dorosłą, to wiadomo Marek jest i już".

Kolejny rozmówca także doświadczył relacji z kobietą. Dla mężczyzny był to bardzo ważny związek uczuciowy i wielką wagę nadawał bliskości towarzyszącej tej relacji. Badany doświadczył intymności i bliskości fizycznej, które wzbudziły u niego pożądanie do kobiety. Wcześniej nigdy nie doświadczył takich emocji, ponieważ to była jego pierwsza dziewczyna:

Mężczyzna nr 2: „Ja miałem kiedyś dziewczynę (...) no wiadomo, co robiliśmy, no wie pani co robią zakochani, całowaliśmy się i przytulaliśmy, no ja chciałem więcej, bo to fajnie tak było, że ja potem spać nie mogłem, bo o niej myślałem ... (...)".

Mężczyzna nr 2: „No to trzeba sobie znaleźć drugą dziewczynę, ale nie ma żadnej, która by mi się podobała, na razie nie ma. (...) Chciałbym bo blisko kogoś masz koło siebie też..., i przytulić się możesz i wie pani... (śmiech)".

Związek uczuciowy jest także bardzo ważny dla kolejnej narratorki. Wzorzec kochających się rodziców wyniosła z domu rodzinnego i taką samą relację chciałaby stworzyć ze swoim mężem. Badana ma nadzieję, że jej mąż zmieni swoje zachowanie (obecnie odbywa karę pozbawienia wolności) i będzie mogła na nim polegać w każdej kwestii dotyczącej ich wspólnego życia:

Kobieta nr 4: „Chciałabym żeby mąż się zmienił, i żebym mogła tak bardziej liczyć..., bardziej polegać na nim..., żeby było tak jak inni..., patrząc na różne małżeństwa to tak czasami zazdroszczę, że tak się im układa, ale no co? Nie wolno się poddawać..., nie wolno po prostu człowieka przekreślać...".

Kobieta $\mathrm{nr} 4:$ ",(..) no chciałabym, żeby razem decydować o naszym życiu, i żeby on też był taki bardziej odpowiedzialny za nas, bo na razie..., ale ja jeszcze czeka, bo nie wolno tak przekreślać życia".

Kobieta nr 4: „Moim marzeniem jest to, żeby..., mój mąż zmądrzał..., i w końcu wydoroślał...".

Związkom uczuciowym towarzyszą także negatywne emocje. Rozmówcy doświadczyli uczucia żalu, zawiedzenia, rozczarowania. Widać to na przykład w na- 
rracji mężczyzny, który wspomniał o bliskiej relacji z kobietą, ale w dalszej części swojej historii nie powrócił już więcej do tematu tego związku. Zapytany o tę znajomość, odpowiedział dość zdawkowo, ale bardzo wymownie:

Mężczyzna nr 1: „Było minęło i nie ma o czym mówić. Serce czasami boli, ale koniec tematu". Oznacza to być może, że relacja ta była ważna dla niego i być może nadal nie pogodził się z utratą bliskiej mu kobiety:

Mężczyzna nr 1: „Miałem dziewczynę, taką fajną, ale ona nie chciała na wsi zostać, tylko do miasta ją ciągnęło (...) matuli to by chyba serce pękło jakbym poszet do miasta. No teraz bym mógł, bo wiadomo sam jestem, ale trzeba pieniądze mieć, żeby mieszkanie kupić, a tyle to ja nie mam. Zresztą tu mi dobrze..., wiadomo, stare śmieci".

Podobne doświadczenia $\mathrm{w}$ zakresie relacji damsko-męskich miał także inny mężczyzna. Narrator w przeszłości tworzył bliską relację z kobietą, która go zraniła. Uczucie to było dla niego bardzo ważne, bo jak sam podkreśla „była miłość". Od tamtej pory nie udało się mu doświadczyć takiego uczucia, chociaż bardzo chciałaby. Tęsknota, żal i rozczarowanie wciąż mu towarzyszą:

Mężczyzna nr 2: „(...) ja kiedyś miałem dziewczynę (...). Była miłość, ale jeszcze mi nie przeszło. Już teraz tak nie tęsknię za nią, już teraz nie tak już... (...) już ze dwa lata jak mnie rzuciła będzie".

Rozczarowania doświadczyła także kobieta, która zapytana o męża, ojca swoich dzieci, odpowiedziała bardzo zdecydowanie, że nie chce już być w relacji z mężczyzną. Badana nie chciała więcej opowiadać o swoim byłym mężu, co może oznaczać, że doświadczyła zawodu z jego strony:

Kobieta nr 3: „Nie mam męża. Nie..., Nie chciałabym już męża. Kiedyś chciałam, powiem pani szczerze, kiedyśs chciałam, a teraz powiedziałam, że nie, teraz już nie..., teraz już nie chcę męża".

Kobieta nr 3: „„(...) teraz się słyszy, że ludzie się tam rozwodzą, takie tam..., mnie przerasta już to. Ja już nie chcę męża. Może kiedyś i chciałam mieć, bo wiadomo, dwoje to inaczej tak? Mąż, żona to wspierają się i pomagają..., ale teraz to już..., jakoś sobie radę sama dam..., przez tyle lat to już. Wychowałam córkę to już sobie poradzę...".

W innej narracji mężczyzna opowiedział także o uczuciu do kobiety, która bardzo go zraniła. Rozczarowanie i żal spowodowały, że narrator nadal jest stanu wolnego:

Mężczyzna nr 3: „No nie założyłem rodziny..., no miałem dziewczynę jak byłem młody, ze Samina tak dziewczyna była, no i dostałem taki, kolega dzwonił do mnie, że jest coś nie za bardzo, żeby przyjechać. No przyjechałem, nakryłem tą moją dziewczynę w łóżku leżała, to mnie ładnie zrobiła, później do mnie listy pisała, a ja się zestarzałem później i tak sobie, wie pani, od tego, i tak później zostało. A teraz to już wie pani..., no 60 lat to już mówią, że stary...". 
Ostatnia grupa relacji odnosi się do partnerstwa w zakresie sfery zawodowej, towarzyskiej, koleżeńskiej i przyjacielskiej. Przykładem może być opowieść narratorki, w której wybrzmiewają doświadczenia z relacji sąsiedzkich. Są one dla niej ważne, bo po pierwsze, są to jedyne relacje koleżeńskie, a po drugie, może podzielić się z sąsiadkami swoimi problemami i spędzić z nimi wolny czas. Ponieważ są to sąsiadki z tej samej kamienicy, w której mieszka narratorka, to bardzo dobrze znają jej sytuację. Stąd rozmowa z nimi nie jest dla niej krępująca, bowiem można odnieść wrażenie, że badana jest bardzo skrytą osobą:

Kobieta nr 2: „Ta sąsiadka fajna..., Tak..., no sąsiadki takie fajne są..., można pogadać, porozmawiać, odprężyć się czy herbatę wypić nawet, tak ooo..., i tylko tak. Nigdzie nie chodzę, bo do nikogo nie lubię chodzić".

W innej biografii znaczący Inni to osoby z personelu placówki, w której badany jest uczestnikiem. Do grupy osób znaczących narrator zaliczył także innych uczestników warsztatów terapii zajęciowej. W całej narracji mężczyzna poświęcił dużo miejsca tym relacjom, dzięki którym czuje się potrzebny, spełniony, a także otrzymuje potrzebne mu wsparcie i pomoc:

Mężczyzna nr 3: „„(...) ale ja tu teraz jestem liderem, prowadzę z Panią Gosią, pomaga mi dużo i powiedziałem, że walczę o swoje prawa o ..., ona mi tak pomogła, że teraz to ja mam święty spokój"

Mężczyzna nr 3: „Ja to miałem rozmawiać z Panią Kamilą, (...) a ona mówi Panie Piotrze to jest ważne... Czy to jest ważne dla Pana, że ktoś doceniają? To jest..., nie chodzi o pieniądze, mnie chodzi tylko o docenianie, że mnie tylko doceniają, że ja jestem $\mathrm{z}$ tego zadowolony, że mnie ktoś docenia jeszcze, nie?".

Badany nawiązuje także inne relacje towarzyskie, ale za każdym razem punktem odniesienia są te nawiązane z uczestnikami i personelem placówki:

Mężczyzna nr 3: „(...) u siebie mam bardzo duże grono przyjaciół. Chodzę do koleżanki do kolegi. Chodzimy, się schodzimy, kawki se pijemy, rozmawiamy sobie...,a tutaj tym bardziej, a tutaj to ja nie wiedziałem, że jeden drugiemu tutaj tak dłoń pomocną poda, że coś...czekoladę...teraz taki Andrzej siedzi na dyżurze i on mi przyniósł czekoladę. Ja mówię co Ty masz? Ja się popłakałem....ale ja nie mogę mówię...weź, bo ja Cię bardzo lubię, (...)".

Podobną satysfakcję z kontaktów koleżeńskich nawiązanych podczas pobytu w placówce czerpie kobieta, dla której spotkania z ludźmi są okazją do rozmów z nimi, do uzyskania wsparcia jej potrzebnego. Kobieta czuje się osaczona przez rodziców, którzy w dalszym ciągu traktują ją bardzo dziecinnie. Wobec czego relacje poza domem są dla niej jedyną oznaką uznania jej dorosłości:

Kobieta nr 5: „Dla mnie to jest satysfakcja, spotykanie się z ludźmi, jak to się mówi..., przyjemność taką, że jest się wśród ludzi i zawsze można jakieś tam, no nie wiem..., doradzić się kogoś czy ten...". 
Kobieta w swojej opowieści nie wspomina o innych związkach koleżeńskich. Życie poza warsztatem także opiera się na relacjach i znajomościach zawartych w placówce:

Kobieta nr 5: „„(...) no bo wspierają tu też..., mam wpierające osoby też, uczymy się też, dużo robimy...i chodzimy na targi publiczne też...gratulują nam jak coś pokazujemy, co robimy. Jak pokazujemy to jeździmy po całym świecie...po całej Polsce jak pokazujemy całemu światu i publiczność...".

Kobieta nr 5: „Fajnie, dobrze się czuję, mam tu znajomych, dużo, wiadomo. Można spotykać się ze znajomymi, można wyjść do ludzi i spotykać się częściej. Spotykam się i rozmawiam, czuję się jak koleżanka, żeby porozmawiać, spotykać się poza warsztatem. (...) spotykamy się na kawę, na spacerze i $\mathrm{w}$ domu".

Kobieta nr 5: „„(..) bo wiem, że mogę zawsze na nich polegaći pomogą mi w każdej sytuacji, bo nieraz ciężko jest, to wiadomo".

Osobą znacząc w przypadku kolejnej badanej jest przełożona, która poza wsparciem na polu zawodowym, udziela jej także niezbędnej pomocy w zakresie wychowania dziecka z niepełnosprawnością. Przełożona, która okazała zainteresowanie, bezinteresowną pomoc i wsparcie, zyskała ogromny szacunek ze strony badanej. W życiu narratorki jest to jedyna obca osoba, która pochyliła się nad jej problemami, toteż ta relacja jest dla niej wyjątkowa:

Kobieta nr 3: „(...) Także, że ja wychowuję, wie pani, sama to jest naprawdę ciężko, bardzo jest ciężko. Tutaj (pracuje na kuchni w wtz - uzup. I. M.) pani Ewa mnie dużo nauczyła, bo ona zawsze pytała co u mnie nie? i tak mi podpowiadała, co mam zrobić $\mathrm{w}$ wielu sprawach, nie".

Kobieta nr 3: „Na kuchni też mi podpowiadała, bo na początku nie wiedziałam, nie? ile no choćby kartofli obrać, ale tak najwięcej powiem pani, to ona o dzieci pytała, bo wiedziała, że córka jest..., wie pani, niepełnosprawna. (...) no ja przychodzę z córką tutaj, bo pani Ewa pomogła mi. (...)".

Kobieta nr 3: „(...) Raczej daję radę, raczej...ciężko ją wychować, bo ma ciężki charakter..., ale jakby nie pani Ewa to ja nie wiem, to może też dałabym radę, ale ciężko nie? Ona powiem pani tak konkretna jest, tu mam przyjść i to zrobić, bo ona wie dobrze jakie ja mam problemy. Ona też ma, bo też ma syna niepełnosprawnego i to wszystko ogrania, a jeszcze mi pomaga i innym te, nie?".

Przejmujący jest fragment narracji mężczyzny, który w przeszłości doświadczył wielu przykrości i nieprzyjemności ze strony osób w miejscu swojego zamieszkania. Negatywne nastawienie otoczenia do własnej osoby odczuł szczególnie, kiedy zaczął uczęszczać do warsztatów terapii zawodowej. Czuł się poniżony i odtrącony przez mieszkańców swojej wsi:

Mężczyzna nr 3: „(...) mówili wtedy, że do czubków tam jeżdżę (...)”. 
Mężczyzna nr 3: „(..) a wcześniej było tak, że mnie zaczepiali. Nie będę tam takich słów używać wulgarnych, bo to... (...)".

Inny fragment narracji także mówi o ograniczonych kontaktach i o doświadczanej samotności. Można jednak odnieść wrażenie, iż izolowanie się od innych osób ze społeczności lokalnej, jest wyborem narratorki, która najlepiej czuje się w środowisku domowym. Kobieta tłumaczy ograniczone kontakty z innymi dużą ilością obowiązków wynikających z prowadzenia gospodarstwa, ale analizując całą narrację można odnieść wrażenie, że czuje się gorsza na tle innych kobiet, które są już mężatkami i matkami:

Kobieta nr 1: „Pani a po co ja mam gdzie wychodzić, a co mnie tu źle w chałupie, cały czas robota jest, a to krowy wydoić, a tu kury nakarmić, ja nie mam czasu tak latać po wsi, bo to czas trzeba mieć. (...) Danka (matka narratorki - uzup. I.M.) wszystkiego sama nie zrobi $(\ldots)^{\prime \prime}$.

Kobieta nr 1: „Pani no jakbym miała męża i dziecko to by tak było jak u wszystkich, a tak to zawsze jestem taką Asią, jakbym małą dziewczynką była...".

Kolejna biografia ukazuje kobietę, która ma świadomość, iż dorosłość to także relacje interpersonalne $\mathrm{z}$ innymi ludźmi, niż tylko z rodzicami. $Z$ analizy narracji wynika, że inne kontakty - poza warsztatowymi - są bardzo incydentalne. Pobyt w placówce to dla badanej ucieczka z "zamkniętego świata” - domu rodzinnego, w którym nadal postrzegana jest jak dziecko. Kobieta ma świadomość, że jest osobą dorosłą, ale rodzice swoją postawą ograniczają ją i tłamszą wszelkie przejawy jej samodzielności. Tak więc wielkiego znaczenia nabiera pobyt w warsztatach, gdzie kontakt z innymi uczestnikami otwiera jej możliwość bycia z ludźmi i sprawia, że tylko w tym miejscu czuje się dorosła:

Kobieta nr 5: „Wiem że mam prawie 40 lat, i wszyscy mi mówią tu że jestem dorosła, np. pani Ela czy Agnieszka to tak..., pani Ela to ona..., no ale cały czas słyszę o tym, że muszę zachowywać się jak dorosła, no ale dla mamusi to ja jestem dziecko cały czas. Najlepiej jak bym siedziała $w$ domu cały czas, (...) ale mnie do ludzi ciągnie, tu mam takie fajne koleżanki i kolegów, no tak fajnie tu jest".

Analiza narracji ukazuje pewne rozgoryczenie narratorki z powodu kruchości relacji, które miały być w jej odczuciu głębsze i trwalsze:

Kobieta nr 5: „Miałam tam koleżanki ale nie utrzymuję tak kontaktu, bo każdy teraz w swoją stronę poszedł i jak to się mówi, się spotka, pogada, ale tak czasami myślałam, że to jest przyjaźn miedzy kimś, że to będzie tak na stałe, ale tak nie jest..., wszystko się rozpada potem i człowiekowi jest tylko przykro..."

Podobne doświadczenie w zakresie nietrwałości relacji ma kolejna narratorka. Relacje z innymi są ważnym elementem jej życia i nadaje im dużą rangę. Z narra- 
cji jednak wynika, że nie wszystkie znajomości okazały się trwałymi, czym sprawiły jej ogromną przykrość:

Kobieta nr 4: „Bardzo dużo znaczą dla mnie przyjaciele. Naprawdę bardzo dużo, ale też no wiadomo, nie, że ludzie bywają różni. Czyli czasem to udają przyjaciół, a mogą gadać za plecami, tak, że też jak coś do kogoś dojdzie to może zranić (...)".

Kobieta nr 4: „Parę osób mnie zraniło, no wiadomo, tak było parę osób..., ale nie chcę...., ale na szczęście mam taki charakter jak mówiłam wcześniej, potrafię sobie radzić w takich sytuacjach".

Podobnie odczucia towarzyszą innej rozmówczyni, która także doświadczyła zawodu ze strony „przyjaciółki” i w chwili obecnej nie jest w stanie - poza matką nikomu zaufać:

Kobieta nr 3: „(...) przyjaciółka to jest moja mama tylko. No mam koleżankę, tak tego, ale to nie jest moja przyjaciółka..., miałam jedną przyjaciółkę kiedyś i powiedziałam, że nie, stop, już nie chcę przyjaciółek...".

\section{Próba rekapitulacji}

Analiza narracji ukazuje rzeczywistość osób z umiarkowaną niepełnosprawnością intelektualną, którzy w sposób subiektywny interpretują doświadczone i doświadczane relacje interpersonalne. Narratorzy nadają tym relacjom indywidualne sensy i znaczenia, które ukazują "prawdę" o wpływie tych więzi na ich życie w przeszłości oraz obecnie realizowanej dorosłości. Relacje interpersonalne z osobami znaczącymi są ważnym elementem ich życia i wpływają na kształtowanie ich tożsamościowego "Ja".

Analiza materiału empirycznego ukazuje różne doświadczenia narratorów $\mathrm{w}$ zakresie relacji społecznych. Osobami znaczącymi w życiu badanych okazali się przede wszystkim rodzice. Kategorie wyłonione w toku subiektywnej interpretacji tych relacji to: wychowanie, opieka, przyjaźń, autorytet, bezpieczeństwo. Są to kategorie mające dla badanych osób pozytywne znaczenie, które znacząco wpłynęły na ich obecne życie. Relacjom z rodzicami zostały także przypisane negatywne kategorie, takie jak: władza, kontrola, przemoc. Są to doświadczenia zarówno z przeszłości, jak i z obecnego życia badanych, które wiążą się z uczuciem żalu, strachu, utraty. Te narracje były bardzo przejmujące, bowiem ukazały nadużycia rodziców wobec badanych osób, nie tylko w okresie dzieciństwa, ale także na etapie ich dorosłości. W zakresie relacji rodzinnych, tylko więzi z siostrami miały znaczenie całkowicie pozytywne. Relacje te interpretowane były jako bezpieczeństwo, wsparcie, uznanie, a siostrze została przypisana rola przewodnika życiowego, doradcy i nauczyciela. 
Drugą grupą relacji istotnych dla rozmówców były te, które dotyczyły ich życia uczuciowego. Z analizy narracji wynika, że związki te utożsamiane są z miłością, partnerstwem, dorosłością, intymnością i bliskością. Są to bardzo pozytywne znaczenia i odgrywają one ogromną rolę w życiu badanych osób. Relacje damsko-męskie kojarzone były ze szczęściem, pożądaniem, potrzebą bliskości, poczuciem bycia dorosłą. Badani relacje te interpretowali także jako rozczarowanie, którego doświadczyli oraz jako alternatywę po utraconej miłości, lub też jako potrzebę bycia w związku partnerskim, którego nie udaje się stworzyć.

Ostatnią grupą relacji z innymi znaczącymi były te, które badani nawiązywali z kolegami, przyjaciółmi, personelem placówki i przełożoną. Wybrzmiały tu kategorie nadane tym relacjom jak: wsparcie, szacunek, uznanie, autorytet, wolność. Można wnioskować, iż relacje te są o tyle istotne dla badanych, że rekompensują wszelkie braki w zakresie relacji z rodzicami. Tworzone więzi z innymi znaczącymi w tej grupie opierają się na uznaniu dorosłości badanych i na respektowaniu realnych potrzeb z niej wynikających. Niektóre znaczenia są bardzo wymowne, jak np. wolność, ucieczka. Wśród subiektywnych interpretacji pojawiły się także znaczenia o zabarwieniu negatywnym, takie jak samotność, izolacja, rozczarowanie. Doświadczenia te były bardzo przykre dla narratorów i chociaż omawiane były w kategorii przeszłości to wybiły swoje piętno na ich obecnym życiu.

Doświadczana rzeczywistość $\mathrm{w}$ zakresie relacji osób z umiarkowaną niepełnosprawnością intelektualną ze znaczącymi Innymi jest trudna. Na każdym etapie swojego życia wchodzą w interakcje z kimś, kto nie akceptuje ich niepełnosprawności, nie uznaje ich prawa do aktywnego uczestnictwa w życiu społecznym lub wykorzystuje ich zaangażowanie. Są to bardzo przykre doświadczenia, szczególnie, jeśli wynikają one z relacji z najbliższymi. Wówczas więzi te nie są tak trwałe, naturalne i szczere, jak być powinny. Są jednak i takie relacje, dzięki którym badani czują się spełnieni, uznani, docenieni, włączeni w nurt życia społecznego w sferze rodzinnej, zawodowej czy towarzyskiej. Są to relacje bardzo budujące, które wpływają pozytywnie na ich poczucie wartości i na odgrywane przez nich role społeczne. W relacjach tych osoba z niepełnosprawnością intelektualną staje się partnerem interakcji.

\section{Bibliografia}

Błeszyńska K. (2001), Niepetnosprawność a struktura identyfikacji społecznych, Wydawnictwo Akademickie "Żak", Warszawa.

Chodkowska M., Szabała B. (2012), Osoby z upośledzeniem umystowym w stereotypowym postrzeganiu społecznym, Wydawnictwo UMCS, Lublin.

Chrzanowska I. (2015), Pedagogika specjalna. Od tradycji do wspótczesności, Oficyna Wydawnicza „Impuls”, Kraków. 
Ćwirynkało K. (2009), Relacje interpersonalne z rówieśnikami osób z lekką niepetnosprawnością intelektualna [w:] Cz. Kosakowski, A. Krause, M. Wójcik (red.), Relacje i doświadczenia społeczne osób z niepetnosprawnością, Wydawnictwo Edukacyjne "Akapit”, Torun-Olsztyn.

Dycht M. (2014), Mity, uprzedzenia, stereotypy a zjawisko piętna $i$ stygmatyzacji niepetnosprawnych wzrokowo [w:] A. Fidelus (red.), Od stereotypu do wykluczenia, Wydawnictwo UKSW, Warszawa.

Hebl M.R., Kleck R.E. (2008), Społeczne konsekwencje niepetnosprawności fizycznej [w:] T.F. Heatherton, R.E. Kleck, M.R. Hebl, J.G. Hull (red.), Społeczna psychologia piętna, Wydawnictwo Naukowe PWN, Warszawa.

Kędzierska H. (2012), Kariery zawodowe nauczycieli. Konteksty - wzory - pola dyskusji, Wydawnictwo Adam Marszałek, Torun.

Kirenko J. (2008), Wobec niepetnosprawności, Wydawnictwo Akademickie: Ośrodek Usług Edukacyjnych, Lublin.

Knoll N., Schwarzer R. (2005), Prawdziwych przyjaciót... Wsparcie społeczne, stres, choroba i śmierć [w:] H. Sęk, R. Cieślak (red.), Wsparcie społeczne, stres izdrowie, PWN, Warszawa.

Konarzewski K. (2000), Jak uprawiać badania oświatowe, Wydawnictwa Szkolne i Pedagogiczne S.A., Warszawa.

Krawiecka K. (2014), Stygmatyzacja osób z niepełnosprawnością intelektualną a rzeczywistość teatralna [w:] A. Fidelus (red.), Od stereotypu do wykluczenia, Wydawnictwo UKSW, Warszawa.

Łobocki M. (2006), Wprowadzenie do metodologii badań pedagogicznych, PWN, Kraków.

Nowak-Dziemianowicz M. (2016), Walka o uznanie w narracjach. Jednostka i wspólnota w procesie poszukiwania tożsamości, Wydawnictwo Naukowe DSW, Wrocław.

Palka S. (2006), Metodologia, badania, praktyka pedagogiczna, Gdańskie Wydawnictwo Psychologiczne, Gdańsk.

Papoutsaki K., Gena A., Kalyva E. (2013), How do Children with Mild Intellectual Disabilitiea Perceive Loneliness?, Europe's Journal of Psychology, nr 9(1).

Rubacha K. (2004), Budowanie teorii pedagogicznych [w:] Z. Kwiecinski, B. Śliwerski (red.), Pedagogika. Podręcznik akademicki, Wydawnictwo Naukowe PWN, Warszawa.

Rzeźnicka-Krupa J. (2011), Niepetnosprawność i pedagogika. Pytanie o podmiot a kwestia tożsamości i zmiany paradygmatycznej dyscypliny, Studia z Teorii Wychowania, t. 2, nr 1(2).

Schütze F. (1997), Trajektoria cierpienia jako przedmiot badań socjologii interpretatywnej, Studia Socjologiczne, $\mathrm{nr} 1$.

Zhen-Qiang W. i wsp. (2010), Correlation between loneliness and social relationship among empty nest elderly in Anhui rural area, China. Aging and Mental Health, 14(1).

Żuraw H. (1999), Procedury jakościowe w pedagogice specjalnej [w:] J. Pańczyk, W Dykcik (red.), Pedagogika specjalna wobec zagrożeń i wyzwań XXI wieku, materiały z obrad XVI sekcji III Zjazdu Pedagogicznego w Poznaniu (21-23 IX 1998), Wydawnictwo UAM - WSPS, WarszawaPoznań. 